\title{
Cyclin-Dependent Kinase-2 Controls Oligodendrocyte Progenitor Cell Cycle Progression and Is Downregulated in Adult Oligodendrocyte Progenitors
}

\author{
Shibeshih Belachew, ${ }^{1}$ Adan A. Aguirre, ${ }^{1}$ Hang Wang, ${ }^{1}$ François Vautier, ${ }^{1}$ Xiaoqing Yuan, ${ }^{1}$ Stacie Anderson, ${ }^{2}$ \\ Martha Kirby, ${ }^{2}$ and Vittorio Gallo ${ }^{1}$ \\ 1 Laboratory of Cellular and Synaptic Neurophysiology, National Institute of Child Health and Human Development, and \\ 'Gene Transfer Laboratory, Hematopoiesis Section, Flow Cytometry Core Unit, National Human Genome Research \\ Institute, National Institutes of Health, Bethesda, Maryland 20892-4495
}

Proliferation of oligodendrocyte progenitor (OP) cells is a crucial process controlling myelination in the CNS. Previous studies demonstrated a correlation between OP proliferation rate and cyclin E/cyclin-dependent kinase-2 (cdk2) activity. To establish a causal link between cyclin E/cdk2 activity and OP proliferation, we selectively modulated cdk2 activity in vitro by transfection of cultured OP cells. Dominant-negative (Dn)-cdk2 overexpression inhibited mitogen-induced OP cell proliferation, whereas wild-type (wt)-cdk2 prevented cell cycle arrest caused by anti-mitotic signals. Dn-cdk2- or wt-cdk2-mediated regulation of $\mathrm{G}_{1} / \mathrm{S}$ transition, per se, did not influence initiation of OP differentiation. To study the function of cyclin E/cdk2 in OP cells during development in vivo, we analyzed cdk2 and cyclin $\mathrm{E}$ expression in cells acutely isolated from transgenic mice expressing the green fluorescent protein (GFP) under the control of the 2 '-3'-cyclic nucleotide 3 '-phosphodiesterase gene pro- moter. Both cyclin E/cdk2 protein levels and activity were decreased in GFP ${ }^{+}$oligodendrocyte lineage cells between postnatal days 4 and 30 . Immunostaining of $\mathrm{NG}^{+} / \mathrm{GFP}^{+} \mathrm{OP}$ cells in brain tissue sections showed a $90 \%$ decrease in overall cell proliferation and cdk2 expression between perinatal and adult cells. However, cdk2 expression within the proliferating (i.e., expressing the proliferating cell nuclear antigen) OP cell population was maintained throughout development. Our data indicate that: (1) cyclin E/cdk2 activity plays a pivotal function in OP cell cycle decisions occurring at $\mathrm{G}_{1} / \mathrm{S}$ checkpoint; (2) initiation of OP differentiation is independent of cyclinE/cdk2 checkpoint, and (3) intrinsic differences in cyclin E/cdk2 expression and activity may underlie the slowly proliferative state that characterizes so-called "quiescent" adult OP cells in vivo.

Key words: cell cycle; cell differentiation; checkpoint genes; CDK; cyclin; fluorescence-activated cell sorting; glia; myelin
In the oligodendroglial lineage, oligodendrocyte progenitor (OP) cells undergo a limited period of proliferation during development, before they exit the cell cycle and terminally differentiate into myelinating oligodendrocytes (Temple and Raff, 1986). Nevertheless, some oligodendrocyte precursor cells have also been shown to lack replicative senescence in vitro and to proliferate indefinitely in the presence of mitogens and in the absence of hydrophobic stimulation (i.e., thyroid hormone) (Tang et al.,

Received June 4, 2002; revised July 17, 2002; accepted July 22, 2002.

This work was supported by the National Institute of Child Health and Human Development Intramural Program. S.B. was supported by the Fonds National de la Recherche Scientifique (Belgium). A.A. was supported by a predoctoral fellowship from Consejo Nacional de Ciencia y Tecnologia (Mexico). We are grateful to Dr. Sander van den Heuvel for generously providing the pCMV-neo-BAM vectors containing the cDNAs for the dominant-negative mutants of cdk2, 4, and 6 and wild-type cdk2. We are particularly grateful to Cristina Ghiani for valuable discussion and for help during the initial phase of this project and to Ann Baron-Van Evercooren for valuable discussion. We thank Li-Jin Chew, Ramesh Chittajallu, Doug Fields, Cristina Ghiani, Chris McBain, Sergio Schinelli, and Beth Stevens for their critical comments on this manuscript.

Correspondence should be addressed to Dr. Vittorio Gallo, Center for Neuroscience Research, Children's Research Institute, Children's National Medical Center, 111 Michigan Avenue, Washington, DC 20010-2970. E-mail: vgallo@ cnmcresearch.org.

S. Belachew's present address: Center for Cellular and Molecular Neurobiology, Department of Neurology, University of Liège, Belgium; and Center for Neuroscience Research, Children's Research Institute, Children's National Medical Center, Washington, DC 20010-2970.

A. Aguirre's and V. Gallo's present address: Center for Neuroscience Research, Children's Research Institute, Children's National Medical Center, Washington, DC 20010-2970.

Copyright (ㄷ) 2002 Society for Neuroscience $\quad 0270-6474 / 02 / 228553-10 \$ 15.00 / 0$
2001). This would suggest that OP proliferation is regulated by extracellular environmental signals acting on molecular intrinsic targets, which are yet undefined, but ultimately linked to the cell cycle machinery.

A significant number of cells with an OP phenotype is still present in the adult CNS, both in the white and gray matter (Levine et al., 2001). Adult OPs proliferate much more slowly than perinatal OPs (Shi et al., 1998; Noble, 2000) and, after CNS damage, they display drastic changes in morphology and increases in NG2 immunoreactivity and mitotic rate (Dawson et al., 2000; Levine et al., 2001). In areas of demyelination, $\mathrm{NG}_{2}{ }^{+}$adult OPs proliferate and increase in number, but do not appear to differentiate into myelinating oligodendrocytes. In vitro studies demonstrated lineage continuity between perinatal and adult OPs, however the molecular basis of their differences in cell proliferation and cell cycle length are still unknown (Noble, 2000).

Cell cycle progression, including G1-S phase transition, is governed by a complex network of biochemical interactions involving the activity of essential components, the cyclin-dependent kinases (cdks) (Morgan, 1997; Kohn, 1999; Roberts, 1999). Because of its intrinsic complexity, cell cycle progression can be regulated at many molecular levels (Sherr and Roberts, 1999) and distinct cdks play pivotal roles in G1-S transition in different neural cell types (Ross, 1996; Ohnuma et al., 2001). The precise roles and relative importance of specific cdks in different neural cell types is still a matter of debate. For example, cdk2 has been shown to play a prominent role in the regulation of Schwann cell 
proliferation (Tikoo et al., 2000), whereas the cdk4/6 signaling pathway is crucial for cortical neural progenitor cell proliferation (Ferguson et al., 2000). In astrocytes, cdk4 is an essential component of cell division (Holland et al., 1998). Clearly, the identification of critical cell type-specific cell cycle regulator(s) under defined physiological conditions will help elucidate mechanisms underlying the growth characteristics of different neural cells in development and disease.

Previous analysis in cultured OP cells demonstrated a decrease of cyclin E/cdk2 kinase activity after permanent cell cycle exit or after reversible cell cycle arrest triggered by extracellular signals (Ghiani et al., 1999a,b; Ghiani and Gallo, 2001). Conversely, cyclin D-associated cdk4/6 kinase activity was only marginally affected during permanent cell cycle withdrawal (Ghiani and Gallo, 2001). In contrast with proliferation, specific molecular targets involved in OP differentiation remain elusive, and little is known about the relationship between cell cycle-related pathways and OP differentiation (Tokumoto et al., 1999; Zezula et al., 2001; Huang et al., 2002).

In the present study, we first used a cell transfection procedure to modify cdk2 activity in cultured perinatal OP cells. We then extended our analysis of cyclin E/cdk2 expression and activity to a transgenic mouse selectively expressing the green fluorescent protein (GFP) in the oligodendrocyte lineage (Belachew et al., 2001; Yuan et al., 2002). Our results establish a direct causal link between cyclin $\mathrm{E} / \mathrm{cdk} 2$ activity and OP cell proliferation, pointing to a pivotal function of cdk2 in changes of OP cell cycle kinetics.

\section{MATERIALS AND METHODS}

Cell culture. The CG-4 oligodendrocyte progenitor cell line was cultured as previously described (Louis et al., 1992). Twenty-four hours before transfection, CG-4 cells were plated onto poly-L-lysine-treated $12 \mathrm{~mm}$ glass coverslips at a density of 50,000 cells per coverslip.

Purified cortical OP cell cultures were prepared as previously described from embryonic day 20 Sprague Dawley rats, using a standard experimental protocol (McCarthy and de Vellis, 1980) with slight modifications (Ghiani et al., 1999a,b). OP cells were expanded for 2 weeks in poly-L-lysine-treated $100 \mathrm{~mm}$ plastic Petri dishes (passaged every $4 \mathrm{~d}$ ) in DME- $\mathrm{N}_{1}$ supplemented with $\mathrm{B}_{104}$ conditioned medium (30\%, v:v) (Louis et al., 1992). One day before transfection, OP cells were transferred onto poly-L-lysine-treated $12 \mathrm{~mm}$ glass coverslips at a density of 50,000 cells per coverslip in DME- $\mathrm{N}_{1}$ medium in the presence of platelet-derived growth factor (PDGF, $10 \mathrm{ng} / \mathrm{ml}$ ) (Upstate Biotechnology, Lake Placid, NY).

DNA constructs and transfection procedure. We used pCytomegalovirus $(\mathrm{CMV})$-neo-BAM vectors containing cDNAs of wild-type cdk2 and dominant-negative mutants of cdk2, cdk4, and cdk6 (van den Heuvel and Harlow, 1993). BamHI-BamHI fragments encompassing wild-type (wt)and dominant negative (Dn)-cdk genes were subcloned into Bluescript SK $(+/-)$ vectors (Stratagene, La Jolla, CA), to allow the following step of downstream cloning of an internal ribosomal entry site (IRES)enhanced green fluorescent protein (EGFP) sequence (catalog \#6064-1; Clontech, Palo Alto, CA). Wt-cdk2-, Dn-cdk2-, Dn-cdk4-, and Dn-cdk6IRES-EGFP fragments were then inserted back into the native pCMVneo-BAM backbone vector, to form plasmids named pCMV:WT2: IRES-GFP, pCMV:DN2:IRES-GFP, pCMV:DN4:IRES-GFP, and pCMV:DN6:IRES-GFP, respectively (Fig. $1 A$ ).

All plasmid constructs were introduced into cultured cells by liposomal transfection in 24-well dishes, using $0.3 \mu \mathrm{g}$ of DNA and $0.8 \mu \mathrm{l}$ of lipofectamine in OPTI-MEM (Life Technologies, Gaithersburg, MD) for each well (50,000 cells per coverslip). The duration of the transfection procedure was $6 \mathrm{hr}$. After transfection, the cells were placed in a mitogenic environment, i.e., DME- $\mathrm{N}_{1}$ supplemented with PDGF (10 $\mathrm{ng} / \mathrm{ml}$ ) for primary OP cells, and DME-N $\mathrm{N}_{1}$ supplemented with $30 \%$ (v:v) $\mathrm{B}_{104}$ conditioned medium for the CG-4 cells. The average efficiency of the transfection procedure (evaluated at $48 \mathrm{hr}$ after transfection) in primary $\mathrm{OP}$ cells $\left(\mathrm{GFP}^{+}\right.$cells per total cells, mean $\left.\pm \mathrm{SD}\right)$ was $9.6 \pm$ $4.2 \%$ for Dn-cdk2 construct, $13.4 \pm 4.2 \%$ for Dn-cdk4, $16.1 \pm 7.0 \%$
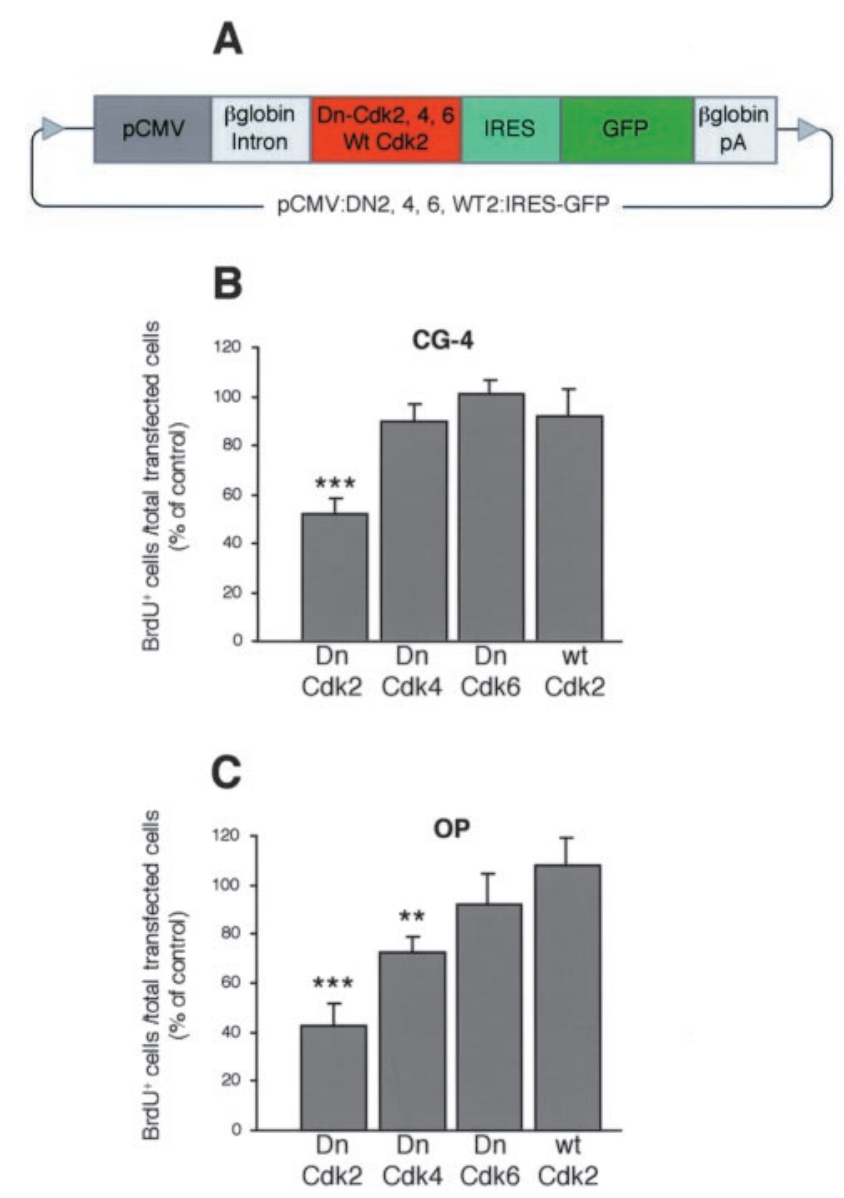

Figure 1. $\mathrm{Cdk} 2$ is a crucial mediator of mitogen-induced OP cell cycle progression. $A$, Several plasmid constructions (pCMV:DN2, 4, 6, WT2: IRES-GFP, $8.8-8.9 \mathrm{~kb}$ ) carrying cDNAs for the wild-type cdk2 or dominant-negative mutants of cdk2, 4, and 6 , under the control of the CMV promoter were generated. The GFP was used as reporter gene and was cloned downstream of an IRES, allowing GFP to be synthesized without fusing with the different kinase proteins. The control vector (pCMV:IRES-GFP, $7.9 \mathrm{~kb}$ ) only contained the IRES-GFP directly driven by the CMV promoter. The plasmids also encompassed the $\beta$-globin intron to enhance transgene expression, and the $\beta$-globin polyadenylation (pA) sequence. $B, C$, Transfected CG-4 and OP cells were cultured in mitogenic medium (see Materials and Methods) and stained after incorporating BrdU $(20 \mu \mathrm{M})$ from 24 to $42 \mathrm{hr}$ post-end of transfection. The BrdU incorporation index $\left(=\mathrm{BrdU}^{+}\right.$cells/total transfected $\mathrm{GFP}^{+}$cells $)$for cells overexpressing the different Dn- and wt-cdks is expressed as a percentage of the corresponding values obtained for cells transfected with the pCMV:IRESGFP control vector, which were $62.6 \pm 3 \%$ for primary OP cells and $90.4 \pm$ $5 \%$ for CG-4 cells (mean \pm SEM). Dn-cdk2 overexpression induced cell cycle arrest both in primary OP and CG-4 cells, whereas Dn-cdk4 marginally inhibited proliferation only in primary OP cells. Histograms represent mean \pm SEM of counts from three separate experiments $\left(>1000 \mathrm{GFP}^{+}\right.$ cells counted for each condition, triplicate coverslips for each). ${ }^{* *} p<0.01$, ${ }^{* * *} p<0.001$, Student's $t$ test.

for Dn-cdk6, and $19.5 \pm 7.8 \%$ for wt-cdk2. The rate of transfection in CG-4 cells was between 30 and $50 \%$ for all the constructs.

$2^{\prime}-3^{\prime}$-cyclic nucleotide 3'-phosphodiesterase-GFP transgenic mouse. The $2^{\prime}$-3'-cyclic nucleotide $3^{\prime}$-phosphodiesterase (CNP)-GFP transgenic mouse was generated by using the $3.7 \mathrm{~kb} X b a \mathrm{I}-H i n \mathrm{dIII}$ sequence, which contains the type I and II promoter core elements of the mouse CNP gene (Gravel et al., 1998; Belachew et al., 2001; Yuan et al., 2002). This fragment was ligated upstream of a $1 \mathrm{~kb} S m a \mathrm{I}-X h o I$ fragment encompassing the coding sequence of EGFP gene (catalog \#6064-1; Clontech) (Belachew et al., 2001; Yuan et al., 2002). A polyadenylation signal from bovine growth hormone was cloned downstream of the fusion gene. A 4.7 $\mathrm{kb} X b a \mathrm{I}-X h o \mathrm{I}$ fragment was excised, purified, and injected into fertilized 
oocytes from F1 females from $\mathrm{FVB} / \mathrm{NxCB} 6$ genetic background. To identify positive transgenic animals, mice were analyzed by both PCR and Southern blot analysis. All animal procedures were performed according to National Institutes of Health guidelines. Immunohistochemical and electrophysiological characterization of $\mathrm{GFP}^{+}$cells in tissue sections from transgenic mice revealed GFP expression in the oligodendroglial lineage (Yuan et al., 2002).

Isolation of oligodendroglial cells by fluorescence-activated cell sorting. Brains were dissected out from postnatal day 4 (P4)-P8, P15, and P30 CNP-GFP mice and from wild-type littermates. Meninges were removed. Brain tissues were cut into small pieces and incubated in enzyme solution (papain, $15 \mathrm{U} / \mathrm{ml}$; type I deoxyribonuclease, $100 \mathrm{U} / \mathrm{ml}$ diluted in PBS solution) at $37^{\circ} \mathrm{C}$ for $20 \mathrm{~min}$. Digested tissues were gently dissociated by passing through successive needles (gauge, $19 \times 1$ inch, $21 \times 1$ inch, and $23 \times 1$ inch). Cell suspensions were then filtered through a $70 \mu \mathrm{m}$ cell strainer, centrifuged, and resuspended in DME- $\mathrm{N}_{1}$ plus $10 \%$ fetal bovine serum (FBS) at a density of $10^{7}$ cells $/ \mathrm{ml}$ for subsequent fluorescence-activated cell sorting (FACS). Cells were analyzed for light forward and side scatter using a FACS Vantage SE instrument (Becton Dickinson, San Jose, CA). To detect GFP fluorescence, cells were analyzed through a $530 \mathrm{~nm}$ bandpass filter, because the excitation wavelength was set at $488 \mathrm{~nm}$ of the argon-ion laser. Cells from negative littermates were used to set the background fluorescence, and a size threshold was used to gate out debris and small fragments. The sorting speed was 2000-4000 cells/sec. After FACS, cells were washed twice and harvested in ice-cold PBS solution.

Western blot and cdk2 activity assay. FACS-sorted cell pellets were resuspended in $100 \mu \mathrm{l}$ of sample buffer [50 mM HEPES, pH 7.4, $150 \mathrm{~mm}$ $\mathrm{NaCl}, 1$ mм EDTA, 2.5 mm EGTA, 1\% Nonidet P-40, $1 \mathrm{~mm} \mathrm{Na}_{3} \mathrm{VO}_{4}, 4$ $\mu \mathrm{M} \mathrm{NaF}, 10 \mu \mathrm{g} / \mathrm{ml}$ leupeptin, $10 \mu \mathrm{g} / \mathrm{ml}$ aprotinin, $10 \mu \mathrm{g} / \mathrm{ml}$ pepstatin, and $1 \mathrm{~mm}$ 4-(2-aminoethyl)benzenesulfonyl fluoride (AEBSF)] and lysed for $45 \mathrm{~min}$ on ice, followed by a brief sonication. The lysate was clarified by centrifugation at $12,000 \mathrm{rpm}$ for $5 \mathrm{~min}$, and the supernatant was collected. An aliquot was taken for protein determination using the Pierce (Rockford, IL) BCA protein assay kit. Protein extracts (18 $\mu \mathrm{g})$ were resolved on a $4-20 \%$ mini-SDS polyacrylamide gel and transferred to Immobilon polyvinylidene difluoride membranes. Equal protein loading was verified by Ponceau S solution (Sigma, St. Louis, MO) reversible staining of the blots. Blots were processed as previously described (Ghiani et al., 1999a,b; Ghiani and Gallo, 2001), using anti-cdk2 (1:500, clone M2, sc-163; Santa Cruz Biotechnology, Santa Cruz, CA) and anti-cyclin E (1:500, clone M20, sc-481; Santa Cruz Biotechnology) antibodies.

Immunostaining in tissue sections and in cell cultures. For cdk2 immunohistochemical experiments, P6 and P30 sections from CNP-GFP transgenic mice were prepared as previously described (Yuan et al., 2002). Frozen sections were blocked at room temperature for at least $1 \mathrm{hr}$ in blocking solution (1\% BSA, $0.3 \%$ Triton X-100, and $20 \%$ normal goat serum in $1 \times$ PBS). Anti-cdk2 (1:200, clone M2, sc-163; Santa Cruz Biotechnology), anti- proliferating cell nuclear antigen (PCNA) (1:50, 05-347; Upstate Biotechnology, Lake Placid, NY), and NG2 (1:1000, AB5320; Chemicon, Temecula, CA) primary antibodies were diluted using carrier solution (1\% BSA, $0.3 \%$ Triton X-100 in $1 \times \mathrm{PBS})$. Brain sections were incubated with primary antibody at $4^{\circ} \mathrm{C}$ overnight. For PCNA staining, tissue sections were treated with cold methanol at $20^{\circ} \mathrm{C}$ for $10 \mathrm{~min}$ before blocking. Rinse was performed in carrier solution at room temperature with three changes of solution every $15 \mathrm{~min}$. Antirabbit and anti-mouse tetramethylrhodamine isothiocyanate- and Cy5conjugated secondary antibodies (Jackson ImmunoResearch Laboratories, West Grove, PA) were diluted 1:200 in carrier solution. Incubation was performed at room temperature for $1 \mathrm{hr}$ and followed by three washes, as described above. Sections were then transferred into $1 \times$ PBS, mounted with Mowiol, and later imaged using a Nikon fluorescence microscope equipped with a Bio-Rad (Hercules, CA) MRC1024 laser confocal scanning system.

For immunocytochemistry of acutely purified OP cells from CNPGFP mice or transfected CG-4 and OP cell cultures, NG2, O4, O1, and BrdU stainings were performed as previously described (Yuan et al., 1998, 2002). For BrdU immunostaining, because the necessary alkaline denaturation of cell DNA $(\mathrm{NaOH} 0.07 \mathrm{~N})$ was partially quenching GFP fluorescence, GFP immunostaining (1:100; polyclonal anti-GFP, Santa Cruz Biotechnology) was performed before BrdU staining to allow accurate detection of transfected cells.

\section{RESULTS}

\section{Cdk2 is a crucial mediator of OP cell cycle progression either in a pro- or anti-mitotic environment}

To establish a causal link between cyclin E/cdk2 activity and OP proliferation, we used cell transfection procedure and performed gain/loss of function experiments. We designed plasmids containing dominant-negative mutants of cdk2, 4, and 6 (Dn-cdk2, 4 and 6) (Fig. 1A) placed under the control of the cytomegalovirus (CMV) promoter with GFP as a reporter gene. These dominant inhibitory mutants hold a single amino acid mutation located in the catalytic cleft of the enzyme that renders them inactive (van den Heuvel and Harlow, 1993). However, Dn-cdks retain their ability to bind their cyclin partners and inactivate the function of endogenous cdks by sequestering the required cyclins (van den Heuvel and Harlow, 1993).

Because previous studies on OP cell cycle kinetics were performed with rat tissue (Ghiani et al., 1999b; Ghiani and Gallo, 2001), transfection experiments were done with purified rat primary cortical OP cells prepared following an established standard culture protocol (McCarthy and de Vellis, 1980) and with progenitors from the rat oligodendroglial cell line CG-4 (Louis et al., 1992). Proliferation was assessed by using bromodeoxyuridine (BrdU) incorporation assays to quantitate GFP-expressing S-phase precursors. In the presence of mitogenic stimulation after transfection, Dn-cdk2 overexpression strongly decreased the number of dividing cells both in primary OP and CG-4 cultures by 58 and $49 \%$, respectively (Fig. $1 B, C$ ). Dn-cdk4 overexpression only inhibited proliferation of primary OP cells by $27 \%$, whereas Dn-cdk6 was devoid of effect (Fig. 1B,C).

In parallel with loss of function experiments, which pointed to a crucial role of cdk2 in mitogen-induced OP proliferation, we also observed that overexpression of the wild-type version of cdk2 (wt-cdk2) in the presence of mitogens did not result in any significant gain of function (Fig. 1B,C). Conversely, when deprived from platelet-derived growth factor (PDGF) stimulation, overexpression of wt-cdk2 was sufficient to maintain a higher percentage of primary OP cells within the cell cycle (Fig. $2 A$, $E-G)$. These results are consistent with the notion that wt-cdk2 overexpression can compensate the downregulation of endogenous cdk2 that constitutively occurs in OP cells after PDGF withdrawal (Ghiani and Gallo, 2001).

We demonstrated that OP cell cycle progression in vitro and in situ (Gallo and Ghiani, 2000) could be influenced by extracellular signals, such as glutamate (Bergles et al., 2000; Gallo and Ghiani, 2000) and norepinephrine (Ghiani et al., 1999b) or by pharmacological $\mathrm{K}^{+}$channel blockade (Ghiani et al., 1999a). In OP cells overexpressing wt-cdk 2 , reversible $\mathrm{G}_{1} / \mathrm{S}$ cell cycle arrest induced by kainic acid, isoproterenol, and tetraethylammonium in the presence of mitogen, was partially but significantly prevented (Fig. 2B-D).

\section{OP cell differentiation is cdk2- and cell cycle number-independent}

To determine whether modifications of OP cell cycle progression could also affect the differentiation process, we studied the emergence of $\mathrm{O}_{4}{ }^{+}$pre-oligodendrocytes and $\mathrm{O}_{1}{ }^{+}$mature oligodendrocytes in transfected cultures. Before transfection, primary OP cultures maintained in PDGF contained $<5 \%$ of $\mathrm{O}_{4}{ }^{+}$and no $\mathrm{O}_{1}{ }^{+}$cells $\left(>90 \%\right.$ of the cells were $\mathrm{GD}_{3}{ }^{+}$or $\mathrm{A} 2 \mathrm{~B}^{+}{ }^{+}$under these 
A

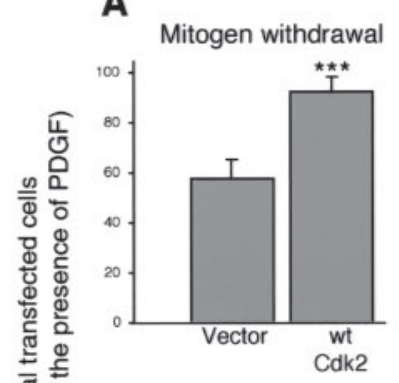

B

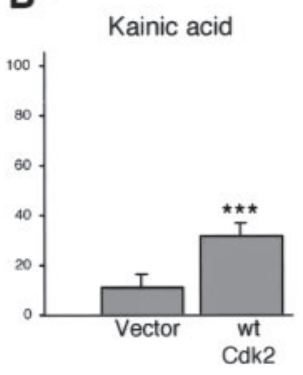

Isoproterenol
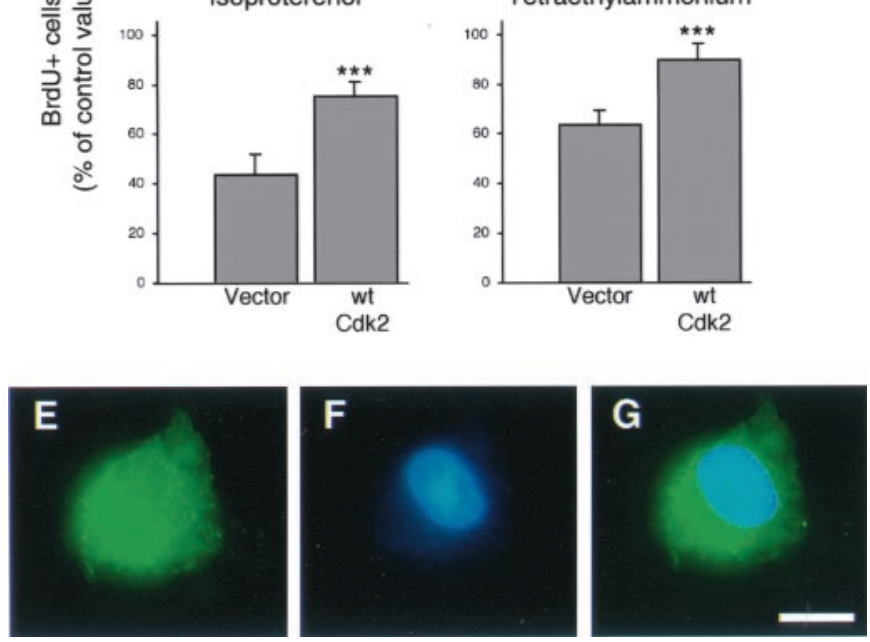

Figure 2. Wt-cdk2 overexpression reverted OP cell cycle arrest associated with the activation of glutamatergic and $\beta$-adrenergic receptors, $\mathrm{K}^{+}$ channels blockade, or mitogen starvation. After transfection, primary OP cells were placed in DME-N ${ }_{1}$ plus PDGF $(10 \mathrm{ng} / \mathrm{ml})$. Twenty-four hours after end of transfection, OP cells were either shifted to growth factor free DME-N $_{1}(A)$, or maintained in PDGF-containing medium supplemented with the glutamate receptor agonist kainic acid $(100 \mu \mathrm{M})(B)$, the $\beta$-adrenergic agonist isoproterenol $(50 \mu \mathrm{M})(C)$, or $\mathrm{K}^{+}$channel blocker tetraethylammonium $(5 \mathrm{~mm})(D)$. Two hours after the medium change, OP cells were incubated with BrdU $(20 \mu \mathrm{M})$ for the next $18 \mathrm{hr}$. Cells transfected with pCMV:WT2:IRES-GFP were compared with those transfected with pCMV:IRES-GFP control vector. Each BrdU incorporation index is expressed as a percentage of values obtained with cells that were transfected with the same constructs, but cultured in the presence of PDGF alone during the entire duration of the experiment. Histograms represent mean $\pm \mathrm{SEM}$ of counts (total $\mathrm{GFP}^{+}$cells counted ranged between 539 and 885 for each condition) from two independent experiments with triplicate coverslips each. $*^{* *} p<0.001$, Student's $t$ test. Separate (GFP in $E$ and BrdU staining in $F$ ) and merged $(G)$ fluorescence views of a proliferating pCMV:WT2:IRES-GFP-transfected OP cell cultured in growth factor free DME-N $\mathrm{D}_{1}$. Scale bar, $7 \mu \mathrm{m}$.

conditions) (Ghiani et al., 1999b; Ghiani and Gallo, 2001) (data not shown). When OP cultures were maintained in the presence of PDGF for $4 \mathrm{~d}$ after transfection, the overexpression of Dncdk2, 4, 6, and wt-cdk2 did not influence oligodendrocyte differentiation, which remained very low $\left(<2 \%\right.$ of $\mathrm{O}_{1}{ }^{+}$cells) (Fig. $3 A, B)$. In this mitogenic environment, thyroid hormone $\left(\mathrm{T}_{3}\right)$ increased, as expected, the proportion of $\mathrm{O}_{4}{ }^{+}$cells (Fig. 3, compare $A, C)$ and induced the appearance of $15-20 \%$ of $\mathrm{O}_{1}{ }^{+}$ cells (Fig. 3, compare $B, D$ ). Furthermore, the presence of $\mathrm{T}_{3}$ did not stimulate growth-arrested OP cells overexpressing Dn-cdk2 or 4 to differentiate more rapidly than OP cells transfected with the control vector (Fig. 3C,D). Finally, in mitogen-free medium, we also observed an increase of OP cell differentiation (Fig. 3,
A
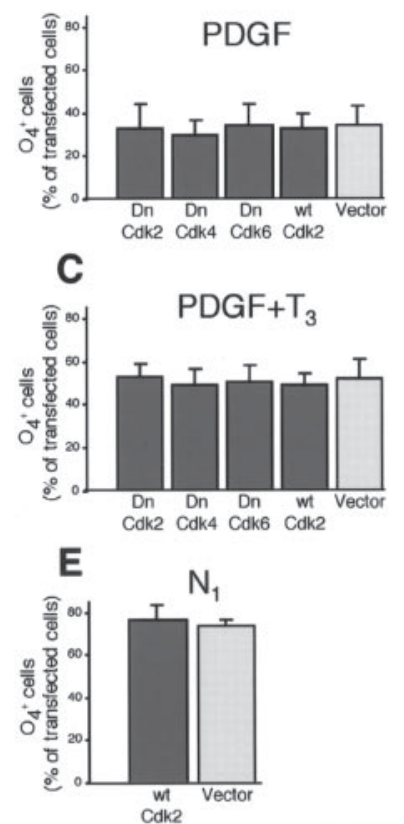

$\mathrm{N}_{1}$

B

$F$

$\mathrm{N}_{1}$
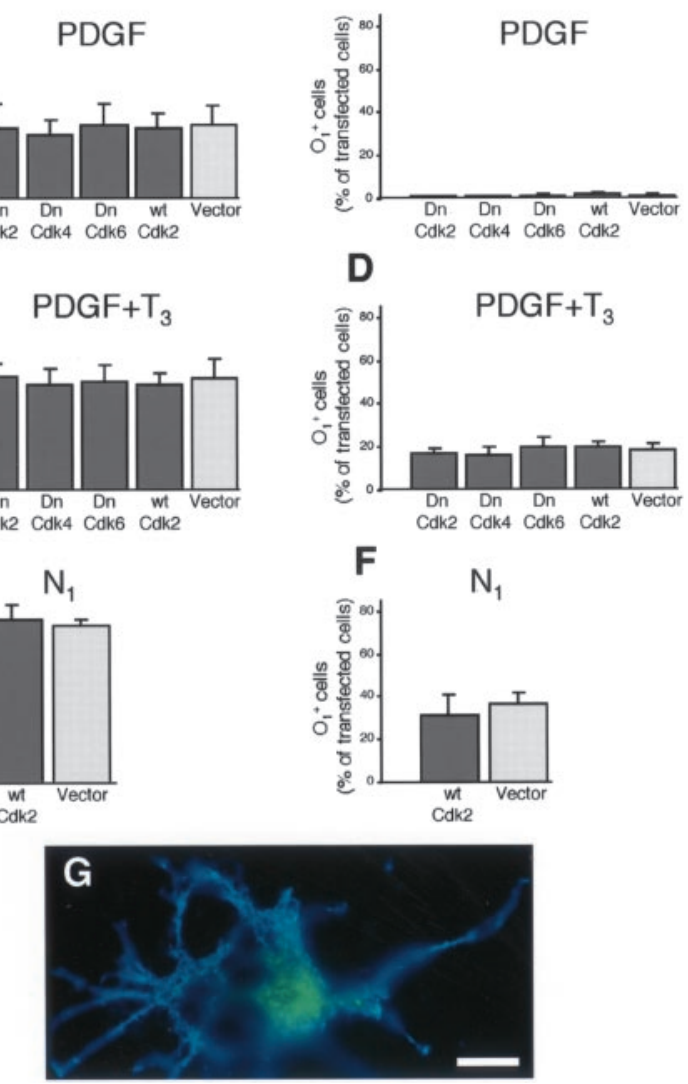

.

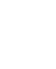
affect differentiation. $\mathrm{O}_{4}$ and $\mathrm{O}_{1}$ immunophenotypes were assessed $4 \mathrm{~d}$ after transfection (pCMV:DN2, 4, 6, WT2:IRES-GFP and pCMV:IRESGFP) of OP cells kept in a mitogenic environment (DME-N ${ }_{1}$ plus PDGF $10 \mathrm{ng} / \mathrm{ml})$ with $(C, D)$ or without $(A, B)$ tri-iodothyronine $\left(T_{3} ; 50 \mathrm{ng} / \mathrm{ml}\right)$. Conversely, we also analyzed $\mathrm{O}_{4}$ and $\mathrm{O}_{1}$ emergence $4 \mathrm{~d}$ after transfecting (pCMV:IRES-GFP versus pCMV:WT2:IRES-GFP) OP cells that had been transferred into cell cycle arresting conditions (i.e., DME-N $\mathrm{D}_{1}$ ), $24 \mathrm{hr}$ after end of transfection $(E, F)$. $G$, Double fluorescence view of an $\mathrm{O}_{1}{ }^{+}$ (blue) mature oligodendrocyte overexpressing wt-cdk2 (GFP in green). Scale bar, $7 \mu \mathrm{m}$. Histograms represent mean \pm SEM of counts (total $\mathrm{GFP}^{+}$cells counted ranged between 427 and 1106 for each condition) from three independent experiments with triplicate coverslips each.

compare $A, E$ and $B, F)$, but overexpression of wt-cdk2, despite maintaining OP cells within the cell cycle (Fig. $2 A$ ), did not induce a more immature phenotype (Fig. $3 E-G$ )

\section{Developmental regulation of cyclin E/cdk2 expression and activity in OP cells in vivo}

To quantitate cyclin $\mathrm{E}$ and cdk2 expression in the oligodendroglial lineage in vivo, we took advantage of a transgenic mouse expressing the GFP under the control of the CNP promoter (Belachew et al., 2001; Yuan et al., 2002). In this transgenic mouse, GFP expression was targeted to the oligodendroglial lineage (Belachew et al., 2001; Yuan et al., 2002). Acutely dissociated $\mathrm{GFP}^{+}$oligodendroglial cells from CNP-GFP mice at different developmental stages (P4-P30) were purified by FACS. Unlike in tissue sections (Yuan et al., 2002), we observed that the proportion of $\mathrm{NG}_{2}{ }^{+}$and $\mathrm{O}_{4}{ }^{+}$cells among acutely purified $\mathrm{CNP}-$ $\mathrm{GFP}^{+}$oligodendroglial cells was not significantly different between FACS-sorted cell suspensions derived from early (P4) or adult (P30) transgenic mice (Fig. 4A). On the other hand, the proportion of $\mathrm{O}^{+}$cells significantly increased between $\mathrm{P} 4$ and 
A

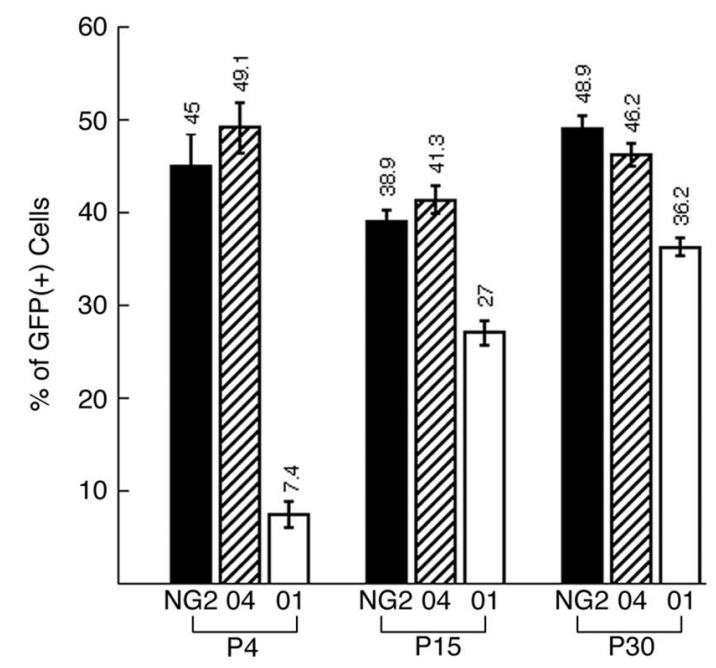

B

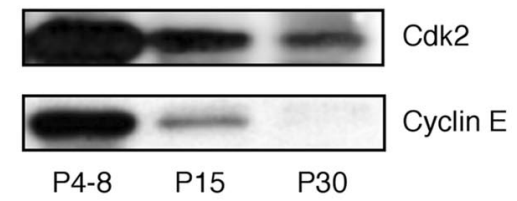

D

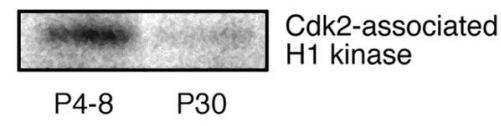

E

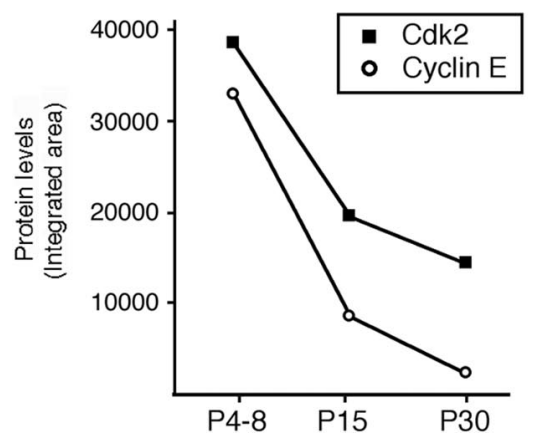

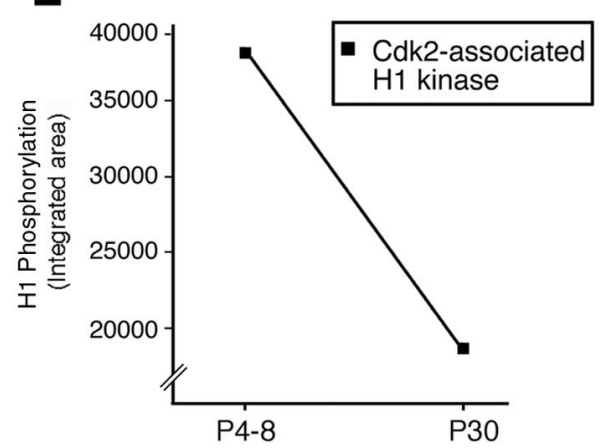

Figure 4. Cyclin E/cdk2 levels and activity decrease in oligodendroglial cells during development in vivo. $A$, Immunophenotype of acutely isolated $\mathrm{CNP}-\mathrm{GFP}^{+}$oligodendroglial cells after FACS purification. We previously demonstrated that GFP expression in CNPGFP transgenic mice was restricted to oligodendrocyte lineage cells (Belachew et al., 2001; Yuan et al., 2002), and that the FACS procedure resulted in a $100 \%$ pure population of GFP ${ }^{+}$cells whose antigenic properties were identical to those in vivo (Yuan et al., 2002). Values represent the percentage (mean \pm $\mathrm{SEM}$ ) of $\mathrm{NG}_{2}{ }^{+}, \mathrm{O}_{4}{ }^{+}$, and $\mathrm{O}_{1}{ }^{+}$cells in FACsorted cell suspensions derived from P4, P15, and P30 CNP-GFP transgenic mice. Total cells counted ranged from 652 to 2185 for each condition. $B$, Western blot analysis of cdk 2 and cyclin E expression was performed with samples containing pure oligodendroglial cells freshly isolated from postnatal P4-P8, P15, and P30 brains. Samples were obtained by FACS of $\mathrm{GFP}^{+}$cells from CNP-GFP transgenic mice. FAC-sorted cells were pooled from a total of 15 brains for each experimental time point. $C$, Values were determined by densitometric analysis of the autoradiographs shown in $B$ and are expressed in arbitrary units. $D$, Cdk2-associated histone H1-kinase activity was measured in FACS-purified CNP-GFP ${ }^{+}$ cells at $\mathrm{P} 4-\mathrm{P} 8$ and $\mathrm{P} 30$, as previously described (Ghiani and Gallo, 2001). Western blot FACsorted cells were pooled from a total of 15 brains for each experimental time point. $E$, Values were determined by densitometric analysis of the autoradiograph shown in $D$ and are expressed in arbitrary units.
P30 (Fig. 4A). The steady percentage of $\mathrm{NG}^{+}$and $\mathrm{O} 4^{+}$cells in the $\mathrm{GFP}^{+}$cell suspensions between P4 and P30 most likely reflects the better survival of immature oligodendroglial cells during the dissociation procedure. At least in part, this could be caused by a loss of cell-to-cell contacts of mature oligodendrocytes in cell suspension. Importantly, as previously demonstrated (Yuan et al., 2002), all the $\mathrm{NG}^{+}$OP cells isolated from our CNP-GFP mice were $\mathrm{GFP}^{+}$. We never distinguished a subpopulation of $\mathrm{NG}_{2}{ }^{+} / \mathrm{GFP}$-negative cells, as reported in the transgenic mouse strain expressing the GFP under the proteolipid protein (PLP) promoter (Mallon et al., 2002).

Western blot analysis of protein extracts from FACS-purified $\mathrm{GFP}^{+}$cells revealed higher levels of cdk2 and cyclin E expression at the early postnatal period (P4-P8) (Fig. 4B,C). In FACSpurified $\mathrm{CNP}-\mathrm{GFP}^{+}$oligodendrocyte lineage cells, a $65 \%$ decrease of cdk2 and a $95 \%$ reduction of cyclin $\mathrm{E}$ protein expression were observed between P4-P8 and P30 (Fig. 4B,C). Similarly, we also observed a drastic $(>50 \%)$ reduction in cyclinE/cdk2 activity between P4 and P30 (Fig. 4D,E).

To determine whether the developmental regulation of cyclinE/cdk2 occurred in OPs during in vivo development, we performed double immunostaining of $\mathrm{GFP}^{+}$cells in tissue sections from CNP-GFP transgenic mice at P6 and P30. Immunodetection of NG2 chondroitin sulfate proteoglycan was used to identify both perinatal and adult OPs in the subventricular zone (SVZ), subcortical white matter, and cerebellar white matter (Levine et al., 2001). $\mathrm{NG}^{+} / \mathrm{GFP}^{+}$OP cells were immunostained with anti-cdk2 antibodies or with antibodies raised against the PCNA, a DNA replication-associated protein expressed in the nucleus of dividing cells, which was used as a marker of cell proliferation (Hyde-Dunn and Jones, 1997). In the SVZ at P6, the majority of $\mathrm{NG}^{+} / \mathrm{GFP}^{+}$OP cells displayed cytoplasmic staining with anti-cdk2 antibodies (Fig. $5 A-D$ ) and nuclear staining with anti-PCNA antibodies (Fig. $5 E-H$ ). Consistent with the Western blot results shown in Figure 4, cell counting after immunohistochemical analysis of tissue sections demonstrated a 9- to 10-fold decrease in the percentage of $\mathrm{NG}^{+} / \mathrm{GFP}^{+} \mathrm{OP}$ cells expressing cdk2 or PCNA in the SVZ, subcortical white matter, and cerebellar white matter between $\mathrm{P} 6$ and $\mathrm{P} 30$ (Fig. $6 A, B$ ).

Double staining of $\mathrm{GFP}^{+}$cells with anti-cdk2 and anti-PCNA in the same brain regions showed that, both at $\mathrm{P} 6$ and at $\mathrm{P} 30$, $>90 \%$ of the $\mathrm{GFP}^{+} / \mathrm{PCNA}^{+}$cells were also cdk2 ${ }^{+}$(Figs. 7, 8A). 

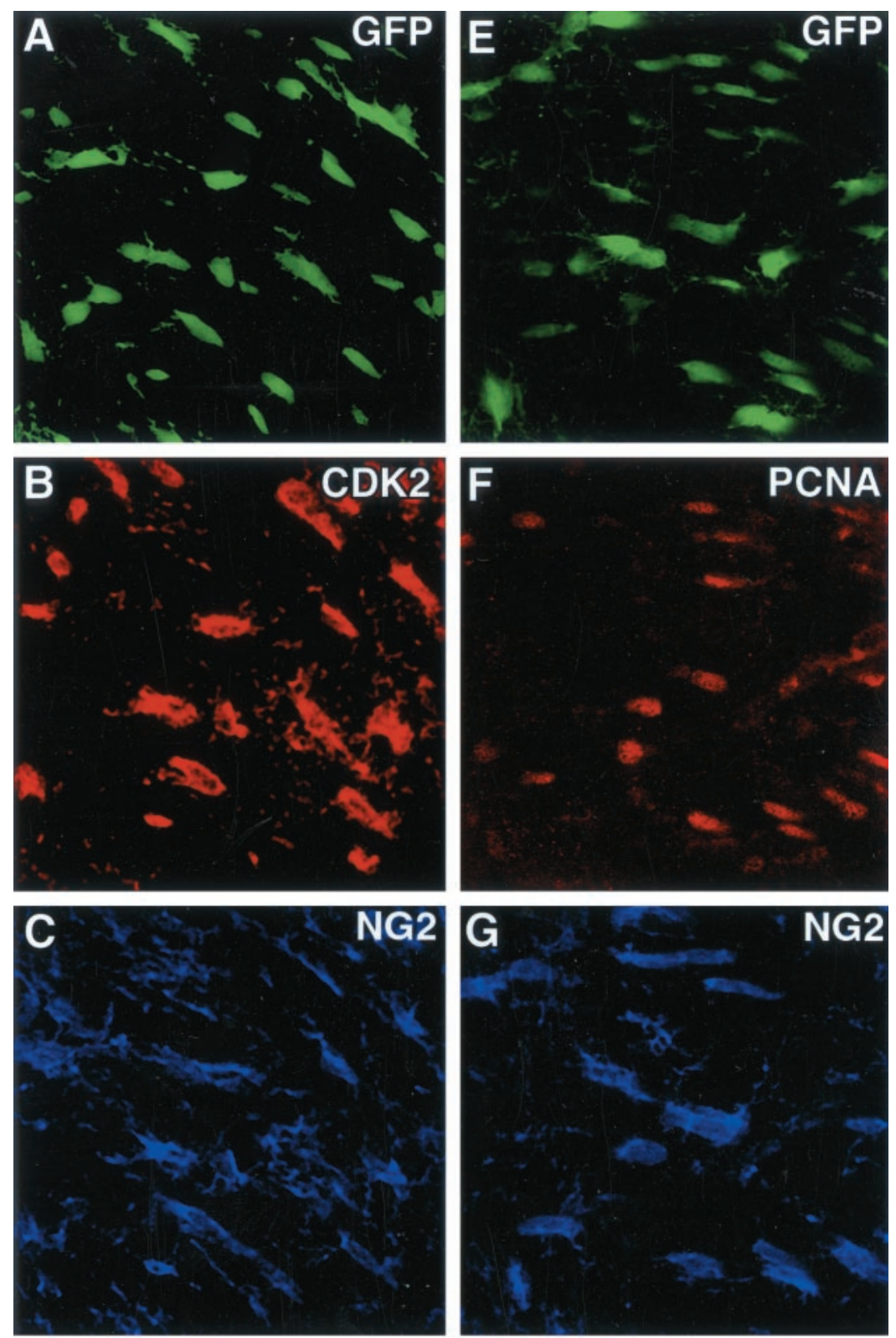

Figure 5. The majority of perinatal $\mathrm{NG}_{2}{ }^{+} \mathrm{OP}$ cells are proliferative and express cdk2 in vivo. Brain sections of SVZ from P6 CNP-GFP mice were immunostained with either ( $A-D$, representing the same field) NG2 (blue) and anti-cdk2 (red) antibodies, or ( $E-H$, representing the same field) with NG2 (blue) and anti-PCNA (red) antibodies. Images were obtained from the subventricular zone. At P6, the majority of $\mathrm{GFP}^{+} / \mathrm{NG}^{+}$cells were also stained with anti-cdk2 $(A-D$, arrows in $D)$ or with anti-PCNA antibodies $(E-H$, arrows in $H$ ) (see Fig. 6 for quantitation). Scale bar, $20 \mu \mathrm{m}$.
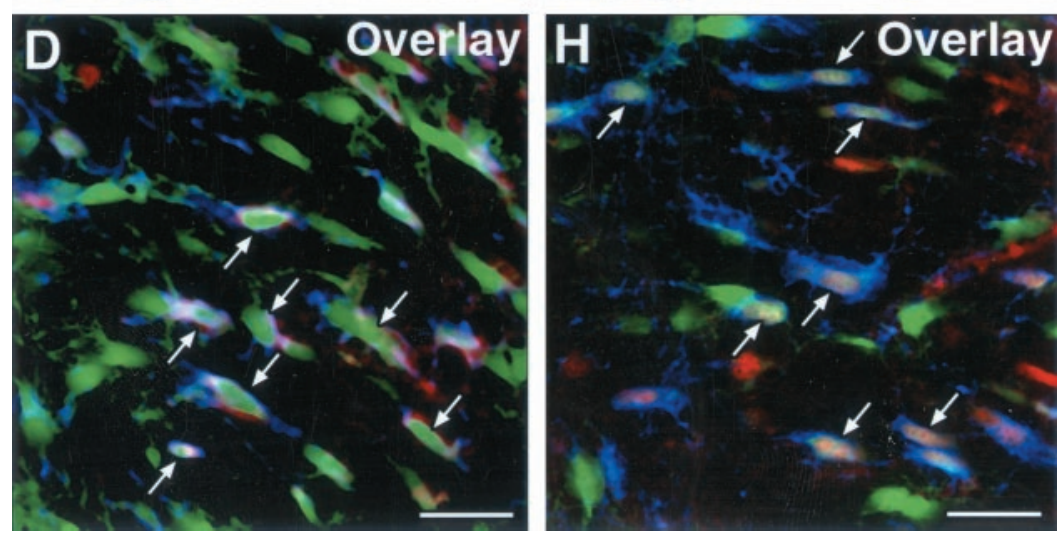

This finding indicates that, within the $\mathrm{GFP}^{+}$oligodendroglial cell population, proliferating cells always expressed cdk2, whereas most of the cdk2-negative cells were nonproliferating (Fig. 7). At P6, 80-90\% of the cdk2-expressing cells were also PCNA $^{+}$(Fig.
$8 B$ ), but at P30, PCNA expression was detected only in $40-60 \%$ of the cdk $2^{+}$cells (Fig. $8 B$ ).

Altogether, these data indicate that cdk 2 is highly expressed in proliferating oligodendroglial cells in vivo throughout develop- 
A

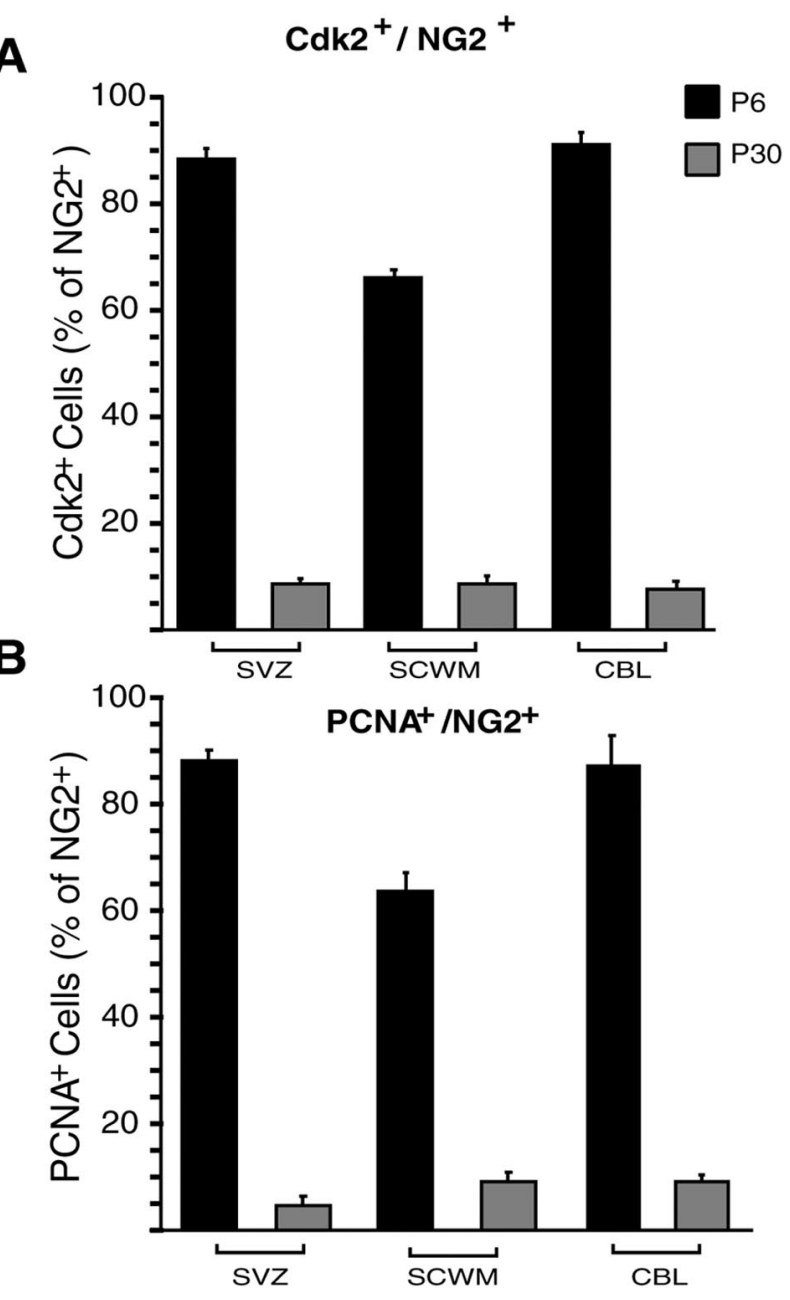

Figure 6. $\mathrm{Cdk} 2$ expression and cell proliferation are downregulated between perinatal and adult oligodendrocyte progenitor cells. Subventricular zone $(S V Z)$, subcortical white matter $(S C W M)$, and cerebellar white matter $(C B L)$ from CNP-GFP mice were analyzed by immunostaining at $\mathrm{P} 6$ and $\mathrm{P} 30$, to assess the number of cdk2- $(A)$ and PCNAexpressing $(B)$ cells within the $\mathrm{NG}^{+} / \mathrm{GFP}^{+}$population at distinct developmental stages. Histograms represent mean \pm SEM. Total GFP ${ }^{+}$ cells counted ranged between 483 and 641 at P6, and between 409 and 455 at $\mathrm{P} 30$.

ment, and that the significant downregulation of cdk2 expression in adult $\mathrm{NG} 2{ }^{+} \mathrm{OP}$ cells is correlated with the event of cell cycle withdrawal.

\section{DISCUSSION}

In the present study, using in vitro transgenesis to overexpress dominant-negative mutants of different cdk genes, we provide evidence that cyclin E/cdk2 activity constitutes an essential component of the mechanism of mitogen-dependent OP cell proliferation. In parallel, we also demonstrate that a decrease of cdk2 activity causally underlies OP cell cycle exit triggered by extracellular signals acting at glutamate and $\beta$-adrenergic receptors, or $\mathrm{K}^{+}$channels. Therefore, our results show that, in OPs, cell cycle pathways activated either in a pro- or in an anti-mitotic environment converge on the common molecular target cdk2.

The finding that cdk4/6 activity was less limiting than cdk2 in the regulation of OP entry into S-phase is consistent with the function of cyclinD/cdk4/6 complexes in different cell types (Jones and Kazlauskas, 2000). In fact, it is likely that reduced cdk4/6 activity is still sufficient to initiate $\mathrm{pRb}$ phosphorylation in early $\mathrm{G}_{1}$ (Jones and Kazlauskas, 2000). This would trigger release of E2F factors, transcriptional activation of cyclin E, and formation of the cyclin $\mathrm{E} / \mathrm{cdk} 2$ complex, which in turn would maintain $\mathrm{pRb}$ phosphorylation until $\mathrm{G}_{1} / \mathrm{S}$ checkpoint (Jones and Kazlauskas, 2000).

Our experiments also demonstrate that cdk2-mediated regulation of OP cell cycle progression did not modify the time course of oligodendrocyte differentiation in the presence of PDGF. Hence, OP cell cycle arrest is a necessary but insufficient condition to trigger differentiation. The uncoupling between OP cell proliferation and differentiation has been demonstrated in cells treated with growth factors or overexpressing cdk inhibitors such as p18, p21, or p27 (Tikoo et al., 1998; Zezula et al., 2001; Tokumoto et al., 2002), however in all these experimental paradigms effects on multiple intracellular pathways could not be excluded. In our cdk2 loss-of-function or gain-of-function experiments, we are selectively targeting one component of the cell cycle machinery and demonstrating that by the specific modification of cdk2 activity we can arrest proliferation without altering differentiation.

Oligodendrocyte differentiation induced by PDGF withdrawal or $\mathrm{T}_{3}$ treatment was not modified by cdk2-mediated manipulations of OP cell cycle kinetics achieved by overexpressing Dn- or wtcdk2. Thus, agents that stimulate OP differentiation may cause irreversible OP cell cycle withdrawal by complex and likely redundant mechanisms, which appear to be unrelated to cyclin E/cdk2 $\mathrm{G}_{1} / \mathrm{S}$ checkpoint. Furthermore, because cdk2-dependent cell cycle arrest did not result in a more immature OP phenotype, nor did cdk2-dependent cell cycle progression accelerate differentiation, our results also provide evidence that OP cells do not "count" the number of cell cycles before they differentiate. Thus, it appears that the yet undefined molecular cues which regulate the differentiation program of OP cells are cell cycle number-independent.

A recent study suggests that at least two molecularly distinct intracellular pathways may be involved in the timer mechanism that triggers OP cell irreversible cell cycle exit and differentiation (Tokumoto et al., 2001). $\mathrm{T}_{3}$-mediated OP cell differentiation appears to depend on a p53 family protein (for review, see Levrero et al., 2000), whereas spontaneous differentiation of OP cells in the presence of PDGF or OP cell differentiation induced by PDGF withdrawal are p53-independent (Tokumoto et al., 2001). $T_{3}$ treatment and PDGF starvation can trigger changes in expression of Cip/Kip and Ink4 CKIs (Ghiani et al., 2001; Tokumoto et al., 2001) that in turn influence cdk2 activity. However, our data show that transgenic modulation of cdk2 activity, per se, did not influence $\mathrm{T}_{3}$ - and PDGF withdrawal-induced differentiation. Therefore, the unknown endpoint mechanism of irreversible cell cycle exit associated with these pro-differentiating conditions are likely to involve distinct pathways that are independent from cyclin E/cdk2 activity. It can be hypothesized that nuclear transcription factors, such as helix-loop-helix proteins, known to stimulate oligodendrocyte differentiation (Kondo and Raff, 2000; Wang et al., 2001) could bypass cyclin E/cdk2 checkpoint and trigger irreversible OP cell cycle exit by directly affecting the phosphorylation state of pRb (Huang et al., 2002).

To correlate our findings on the essential role of cyclin E/cdk2 activity in OP proliferation in culture with OP proliferation in vivo, we took advantage of a transgenic mouse model in which GFP was selectively expressed in the oligodendroglial lineage throughout embryonic and postnatal development (Belachew et al., 2001; Yuan et al., 2002). After a FACS procedure that allowed 

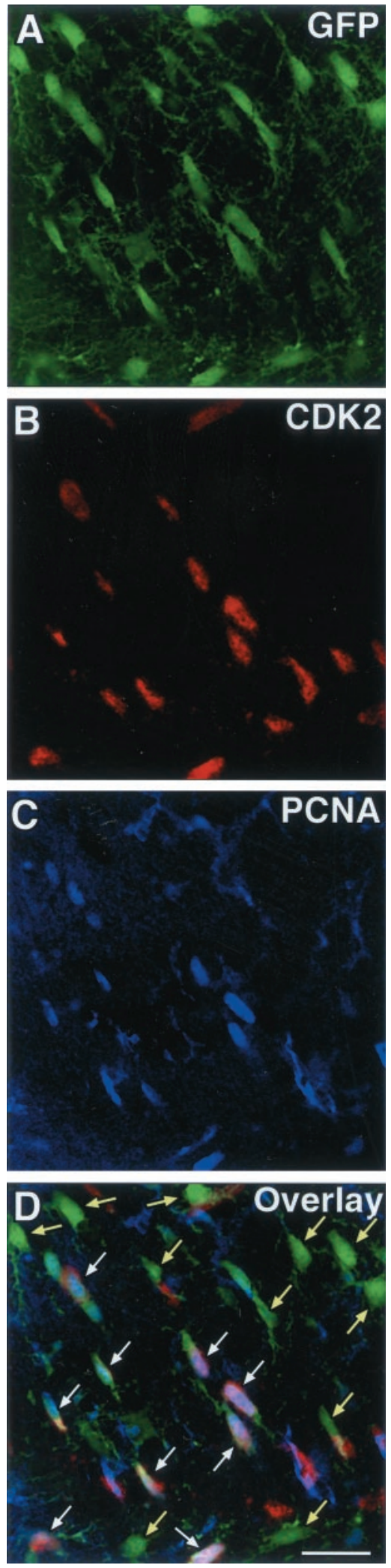

Figure 7. Coexpression of PCNA and cdk2 in $\mathrm{CNP}^{-\mathrm{GFP}^{+}}$cells in vivo. Brain sections from P6 CNP-GFP mice $A-D$, representing the same field were immunostained with anti-cdk2 $(B, r e d)$ and anti-PCNA $(C$, blue $)$ antibodies. Images represent the same microscopic field obtained from the subventricular zone at P6. The majority of proliferating $\mathrm{PCNA}^{+} / \mathrm{GFP}^{+}$ oligodendroglial cells coexpressed cdk2 (white arrows; see Fig. 8 for quantitation), whereas most of the cdk2-negative oligodendroglial cells were found to be nonproliferative, i.e., PCNA-negative ( yellow arrows). Scale bar, $20 \mu \mathrm{m}$.
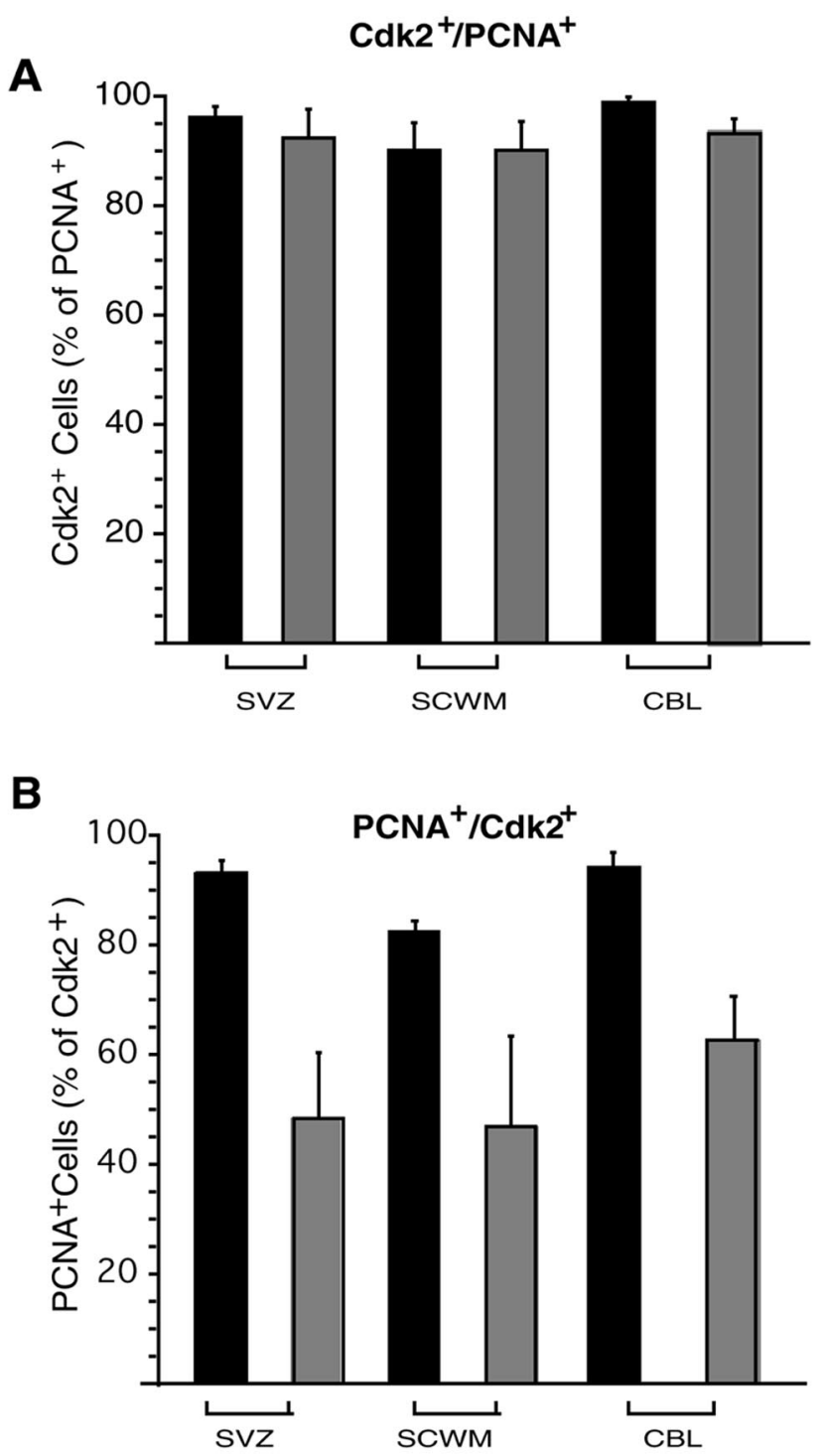

Figure 8. Proliferating $\mathrm{GFP}^{+}$oligodendroglial cells express sustained levels of cdk2 during development. Subventricular zone (SVZ), subcortical white matter $(S C W M)$, and cerebellar white matter $(C B L)$ from CNP-GFP mice were analyzed by immunostaining at P6 and P30, to assess the number of PCNA- and cdk2-co-expressing cells within the $\mathrm{GFP}^{+}$population at distinct developmental stages. $A$ shows the percentage of $\mathrm{PCNA}^{+}$cells also expressing cdk2, whereas $B$ indicates the percentage of cdk2 $2^{+}$cells also expressing PCNA. Histograms represent mean \pm SEM. Total GFP $^{+}$cells counted ranged between 483 and 597 at P6 and between 409 and 455 at P30.

us to purify $\mathrm{GFP}^{+}$oligodendroglial cells at the progenitor stage (Yuan et al., 2002), we were able to demonstrate a downregulation of cyclin $\mathrm{E} / \mathrm{cdk} 2$ activity and cyclin $\mathrm{E}$ and $\mathrm{cdk} 2$ protein expression in OP cells acutely isolated from adult brain.

We also performed a developmental immunohistochemical study of the proportion of cdk2-expressing cells within $\mathrm{NG}^{+}$/ $\mathrm{GFP}^{+}$OP cells in the SVZ, cerebellar white matter, and subcortical white matter. We detected a drastic decrease of both proliferation and cdk2 expression in $\mathrm{NG}_{2}{ }^{+} \mathrm{OP}$ cells between the perinatal period and adulthood. Furthermore, we observed that nearly all the few OP cells which remain proliferative in the adult brain sustained a high level of cdk2 expression. Conversely, about half of cdk2-expressing OPs of the adult brain were found to be 
nonproliferative, which suggests that the decrease of cyclin $\mathrm{E} / \mathrm{cdk} 2$ complex activity and proliferation in postnatal OPs may be initially triggered by a reduction in cyclin E expression. This hypothesis is supported by our Western blot analysis of cyclin E and cdk2 expression in FACS-purified $\mathrm{GFP}^{+}$cells (Fig. 4), indicating a more rapid developmental decline in cyclin $\mathrm{E}$ than in cdk2 levels. Thus, altogether our data strongly suggest that regulation of cyclin $\mathrm{E}$ and $\mathrm{cdk} 2$ expression and cyclin $\mathrm{E} / \mathrm{cdk} 2$ activity within the oligodendroglial lineage in vivo causally underlies the progressive breakdown of OP cell proliferative potential that occurs during postnatal maturation (Wolswijk et al., 1990; Calver et al., 1998; Shi et al., 1998).

Despite an established lineage continuity, adult OP cells are known to differ from their neonatal counterparts in cell cycle time, rate of migration and time course of differentiation (Ffrench-Constant and Raff, 1986; Wolswijk et al., 1990; Shi et al., 1998). Our data show that, besides extrinsic environmental differences at the level of mitogen supply and response (Chan et al., 1990; Wolswijk and Noble, 1992; Engel and Wolswijk, 1996; van Heyningen et al., 2001), a major reason for the slower cell cycle kinetics of adult OPs relies on the intrinsic developmental regulation of the molecular machinery controlling cell cycle $G_{1} / S$ checkpoint. These findings may shed a new light on our understanding of the "quiescent" state of OP cells in human normal adult white matter and in multiple sclerosis lesions (Wolswijk, 1998; Chang et al., 2000; Maeda et al., 2001). Consistent with our hypothesis, a recent study by Sim et al. (2002) demonstrated that the significant attenuation in remyelination efficiency observed in adult OPs as compared to their perinatal counterpart is at least in part due to an impairment in recruitment, that involves both proliferation and migration.

Our results not only provide insights into OP cell cycle decisions and the relationship between OP proliferation and differentiation, but also open new perspectives with respect of our understanding of: (1) the deregulation of proliferation underlying the genesis of OP-derived gliomas (Shoshan et al., 1999), and (2) the failure of remyelination in spite of the persistence of OP cells in CNS demyelinating lesions (Chang et al., 2000). We propose here that, besides acting on extrinsic cues, the molecular strategies aimed at modulating adult OP cell proliferation may need to focus on specifically targeting the cyclinE/cdk2 complex. With regard to genetic engineering techniques, as demonstrated in previous studies (Belachew et al., 2001; Yuan et al., 2002; Mallon et al., 2002), the use of CNP or PLP promoter-driven genes appears to be best suited for loss/gain-of-function experiments selectively targeting adult OP cells.

\section{REFERENCES}

Belachew S, Yuan X, Gallo V (2001) Unraveling oligodendrocyte origin and function by cell-specific transgenesis. Dev Neurosci 23:287-298.

Bergles DE, Roberts JD, Somogyi P, Jahr CE (2000) Glutamatergic synapses on oligodendrocyte precursor cells in the hippocampus. Nature 405:187-191.

Calver AR, Hall AC, Yu WP, Walsh FS, Heath JK, Betsholtz C, Richardson WD (1998) Oligodendrocyte population dynamics and the role of PDGF in vivo. Neuron 20:869-882.

Chan CL, Wigley CB, Berry M (1990) Oligodendrocyte-type 2 astrocyte $(\mathrm{O}-2 \mathrm{~A})$ progenitor cells from neonatal and adult rat optic nerve differ in their responsiveness to platelet-derived growth factor. Brain Res Dev Brain Res 55:275-282.

Chang A, Nishiyama A, Peterson J, Prineas J, Trapp BD (2000) NG2positive oligodendrocyte progenitor cells in adult human brain and multiple sclerosis lesions. J Neurosci 20:6404-6412.

Dawson MRL, Levine JM, Reynolds R (2000) NG2-expressing cells in the central nervous system: are they oligodendroglial progenitors? J Neurosci Res 61:471-479.

Engel U, Wolswijk G (1996) Oligodendrocyte-type-2 astrocyte (O-2A) progenitor cells derived from adult rat spinal cord: in vitro characteristics and response to PDGF, bFGF and NT-3. Glia 16:16-26.

Ferguson KL, Callaghan SM, O'Hare MJ, Park DS, Slack RS (2000) The $\mathrm{Rb}-\mathrm{cdk} 4 / 6$ signaling pathway is critical in neural precursor cell cycle regulation. J Biol Chem 275:33593-33600.

Ffrench-Constant C, Raff MC (1986) Proliferating bipotential glial progenitor cells in adult rat optic nerve. Nature 319:499-502.

Gallo V, Ghiani CA (2000) Glutamate receptors in glia: new cells, new inputs and new functions. Trends Pharmacol Sci 21:252-258.

Ghiani CA, Yuan X, Eisen AM, Knutson PL, DePinho RA, McBain CJ, Gallo V (1999a) Voltage-activated $\mathrm{K}^{+}$channels and membrane depolarization regulate accumulation of the cyclin-dependent kinase inhibitors p27(Kip1) and p21(CIP1) in glial progenitor cells. J Neurosci 19:5380-5392.

Ghiani CA, Eisen AM, Yuan X, DePinho RA, McBain CJ, Gallo V (1999b) Neurotransmitter receptor activation triggers p27(Kip1) and p21(CIP1) accumulation and G1 cell cycle arrest in oligodendrocyte progenitors. Development 126:1077-1090.

Ghiani CA, Gallo V (2001) Inhibition of cyclin E-cyclin-dependent kinase 2 complex formation and activity is associated with cell cycle arrest and withdrawal in oligodendrocyte progenitor cells. J Neurosci 21:1274-1282.

Gravel M, Di Polo A, Valera PB, Braun PE (1998) Four-kilobase sequence of the mouse CNP gene directs spatial and temporal expression of lacZ in transgenic mice. J Neurosci Res 53:393-404.

Holland EC, Hively WP, Gallo V, Varmus HE (1998) Modeling mutations in the $\mathrm{G}_{1}$ arrest pathway in human gliomas: overexpression of $C D K 4$ but not loss of INK4a-ARF induces hyperploidy in cultured mouse astrocytes. Genes Dev 12:3644-3649.

Huang Z, Tang XM, Cambi F (2002) Down-regulation of the retinoblastoma protein $(\mathrm{rb})$ is associated with rat oligodendrocyte differentiation. Mol Cell Neurosci 19:250-262.

Hyde-Dunn J, Jones GE (1997) Visualization of cell replication using antibody to proliferating cell nuclear antigen. Methods Mol Biol 75:341-347.

Jones SM, Kazlauskas A (2000) Connecting signaling and cell cycle progression in growth factor-stimulated cells. Oncogene 19:5558-5567.

Kohn KW (1999) Molecular interaction map of the mammalian cell cycle control and DNA repair systems. Mol Biol Cell 10:2703-2734.

Kondo T, Raff M (2000) Basic helix-loop-helix proteins and the timing of oligodendrocyte differentiation. Development 127:2989-2998.

Levine JM, Reynolds R, Fawcett JW (2001) The oligodendrocyte precursor cell in health and disease. Trends Neurosci 24:39-47.

Levrero M, De Laurenzi V, Costanzo A, Gong J, Wang JY, Melino G (2000) The p53/p63/p73 family of transcription factors: overlapping and distinct functions. J Cell Sci 113:1661-1670.

Louis JC, Magal E, Muir D, Manthorpe M, Varon S (1992) CG-4, a new bipotential glial cell line from rat brain, is capable of differentiating in vitro into either mature oligodendrocytes or type-2 astrocytes. J Neurosci Res 31:193-204.

Maeda Y, Solanky M, Menonna J, Chapin J, Li W, Dowling P (2001) Platelet-derived growth factor-alpha receptor-positive oligodendroglia are frequent in multiple sclerosis lesions. Ann Neurol 49:776-785.

Mallon BS, Shick HE, Kidd GJ, Macklin WB (2002) Proteolipid promoter activity distinguishes two populations of NG2-positive cells throughout neonatal cortical development. J Neurosci 22:876-885.

McCarthy KD, de Vellis J (1980) Preparation of separate astroglial and oligodendroglial cell cultures from rat cerebral tissue. J Cell Biol 85:890-902

Morgan DO (1997) Cyclin-dependent kinases: engines, clocks, and microprocessors. Annu Rev Cell Dev Biol 13:261-291.

Noble M (2000) Precursor cell transitions in oligodendrocyte development. J Cell Biol 148:839-841.

Ohnuma S, Philpott A, Harris WA (2001) Cell cycle and cell fate in the nervous system. Curr Opin Neurobiol 11:66-73.

Roberts JM (1999) Evolving ideas about cyclins. Cell 98:129-132.

Ross ME (1996) Cell division and the nervous system: regulating the cycle from neural differentiation to death. Trends Neurosci 19:62-68.

Sherr CJ, Roberts JM (1999) CDK inhibitors: positive and negative regulators of G1-phase progression. Genes Dev 13:1501-1512.

Shi J, Marinovich A, Barres BA (1998) Purification and characterization of adult oligodendrocyte precursor cells from the rat optic nerve. J Neurosci 18:4627-4636.

Shoshan Y, Nishiyama A, Chang A, Mork S, Barnett GH, Cowell JK, Trapp BD, Staugaitis SM (1999) Expression of oligodendrocyte progenitor cell antigens by gliomas: implications for the histogenesis of brain tumors. Proc Natl Acad Sci USA 96:10361-10366.

Sim FJ, Zhao C, Penderis J, Franklin RJM (2002) The age-related decrease in CNS remyelination efficiency is attributable to an impairment of both oligodendrocyte progenitor recruitment and differentiation. J Neurosci 22:2451-2459.

Tang DG, Tokumoto YM, Apperly JA, Lloyd AC, Raff MC (2001) Lack of replicative senescence in cultured rat oligodendrocyte precursor cells. Science 291:868-871.

Temple S, Raff MC (1986) Clonal analysis of oligodendrocyte develop- 
ment in culture: evidence for a developmental clock that counts cell divisions. Cell 44:773-779.

Tikoo R, Osterhout DJ, Casaccia-Bonnefil P, Seth P, Koff A, Chao MV (1998) Ectopic expression of p27Kip1 in oligodendrocyte progenitor cells results in cell-cycle growth arrest. J Neurobiol 36:431-440.

Tikoo R, Zanazzi G, Shiffman D, Salzer J, Chao MV (2000) Cell cycle control of Schwann cell proliferation; role of cyclin-dependent kinase-2. J Neurosci 20:4627-4634.

Tokumoto YM, Durand B, Raff MC (1999) An analysis of the early events when oligodendrocyte precursor cells are triggered to differentiate by thyroid hormone, retinoic acid, or PDGF withdrawal. Dev Biol 213:327-339.

Tokumoto YM, Tang DG, Raff MC (2001) Two molecularly distinct intracellular pathways to oligodendrocyte differentiation: role of a p53 family protein. EMBO J 20:5261-5268.

Tokumoto YM, Apperly JA, Gao FB, Raff MC (2002) Posttranscriptional regulation of $\mathrm{p} 18$ and $\mathrm{p} 27 \mathrm{Cdk}$ inhibitor proteins and the timing of oligodendrocyte differentiation. Dev Biol 245:224-234.

van den Heuvel S, Harlow E (1993) Distinct roles for cyclin-dependent kinases in cell cycle control. Science 262:2050-2054.

van Heyningen P, Calver AR, Richardson WD (2001) Control of progenitor cell number by mitogen supply and demand. Curr Biol 11:232-241.

Wang S, Sdrulla A, Johnson JE, Yokota Y, Barres BA (2001) A role for the helix-loop-helix protein Id 2 in the control of oligodendrocyte development. Neuron 29:603-614.

Wolswijk G (1998) Chronic stage multiple sclerosis lesions contain a relatively quiescent population of oligodendrocyte precursor cells. J Neurosci 18:601-609.

Wolswijk G, Noble M (1992) Cooperation between PDGF and FGF converts slowly dividing O-2Aadult progenitor cells to rapidly dividing cells with characteristics of O-2Aperinatal progenitor cells. J Cell Biol 118:889-900.

Wolswijk G, Riddle PN, Noble M (1990) Coexistence of perinatal and adult forms of a glial progenitor cell during development of the rat optic nerve. Development 109:691-698.

Yuan X, Eisen AM, McBain CJ, Gallo V (1998) A role for glutamate and its receptors in the regulation of oligodendrocyte development in cerebellar tissue slices. Development 125:2901-2914.

Yuan X, Chittajallu R, Belachew S, Anderson S, McBain CJ, Gallo V (2002) Expression of the green fluorescent protein in the oligodendrocyte lineage: a transgenic mouse for developmental and physiological studies. J Neurosci Res, in press.

Zezula J, Casaccia-Bonnefil P, Ezhevsky SA, Osterhout DJ, Levine JM, Dowdy SF, Chao MV, Koff A (2001) p21cip1 is required for the differentiation of oligodendrocytes independently of cell cycle withdrawal. EMBO J 2:27-34 